\title{
Pengelolaan Program Kewirausahaan di Sekolah Menengah Atas di Daerah Istimewa Yogyakarta
}

\author{
Aji Setiawan \\ Universitas Negeri Yogyakarta, Yogyakarta, DIY, Indonesia
}

Corresponding author: Aji Setiawan (E-mail: ajiwan1994@gmail.com)

\begin{abstract}
Abstrak: Penelitian ini bertujuan untuk mendeskripsikan perencanaan, pelaksanaan, dan evaluasi program kewirausahaan Sekolah Menengah Atas Negeri (SMAN) di DIY. Penelitian menggunakan metode kualitatif dengan subjek penelitian yakni penanggung jawab program, koordinator program, dan guru kewirausahaan. Penelitian dilaksanakan pada sekolah penyelenggara program kewirausahaan, yaitu: SMA Negeri 6 Yogyakarta, SMAN 2 Banguntapan, SMAN 1 Turi, dan SMAN 1 Playen. Pengumpulan data dalam penelitian ini menggunakan wawancara, observasi, dan studi dokumen. Uji keabsahan data menggunakan triangulasi sumber. Analisis data menerapkan model interaktif dari Miles, Huberman dan Saldana. Hasil penelitian menunjukkan bahwa (1) perencanaan program kewirausahaan SMAN di DIY dilakukan dengan penetapan tujuan, perencanaan program, perencanaan pembiayaan, dan perencanaan personil; (2) pelaksanaan program kewirausahaan SMAN di DIY meliputi pengorganisasian, koordinasi, dan implementasi kurikulum; (3) evaluasi program kewirausahaan SMAN di DIY dilakukan pada setiap akhir semester oleh tim kewirausahaan sekolah.
\end{abstract}

Kata Kunci: pengelolaan program, program kewirausahaan, program sekolah

\section{The Management of the Entrepreneurship Program at Senior High Schools in Yogyakarta Special Province}

\begin{abstract}
This study aims to describe the planning, implementation and evaluation of the entrepreneurship program at public senior high schools in the Special Region of Yogyakarta. This study used a qualitative approach. The research subjects were the program managers, program coordinators, and teachers of the entrepreneurship program. This study involved four public senior high schools in Bantul. Data collection methods used were interviews, observation, and documentation. To achieve data validity, triangulation of data source was applied. The qualitative analysis model from Miles, Huberman and Saldana was applied as a guidance in the data analysis process. This study found that (1) the planning of entrepreneurship programs involves setting goals, planning programs, finance, and personnel; (2) the implementation of the entrepreneurship programs includes organizing, coordinating and implementing the curriculum; and (3) the evaluation of the entrepreneurship programs is carried out at the end of each semester.
\end{abstract}

Keywords: program management, entrepreneurship program, school program 


\section{PENDAHULUAN}

Pada era modern ini, pesatnya kemajuan ilmu pengetahuan dan teknologi (IPTEK) berdampak pada berbagai sektor. Pada sektor ekonomi, dampak perkembangan IPTEK menuntut peningkatan Sumber Daya Manusia (SDM) agar dapat bersaing dengan bangsa lain. Data dari Badan Pusat Statistik (BPS) pada tahun 2016 menggambarkan rasio jumlah wirausaha dan jumlah penduduk Indonesia sebesar 3,1\%. Angka tersebut sebenarnya telah melampaui batas minimal sebesar $2 \%$, hanya saja rasio tersebut masih lebih rendah dibandingkan dengan negara lain seperti Malaysia sebesar 5\%, Singapura 7\%, China sebesar 10\%, Jepang 11\%, dan Amerika Serikat sebesar 12\%. Fenomena tersebut masih menjadi perhatian bagi pemerintah dan masyarakat. Paradigma masyarakat masih banyak yang bercita-cita menjadi pegawai negeri sipil, karyawan, dan buruh. Fenomena yang perlu diketahui juga yakni persaingan dalam memperoleh pekerjaan sangatlah ketat. Adanya kebijakan bebas visa di negara-negara Asia oleh Pemerintah Indonesia mengakibatkan persaingan secara langsung dengan tenaga kerja asing dalam hal mendapatkan pekerjaan.

Tidak bisa dipungkiri, saat ini banyak lembaga dan perusahaan lebih mempertimbangkan lulusan pendidikan yang lebih tinggi untuk menjadi calon karyawannya. Lulusan sekolah menengah atas (SMA) atau sekolah menengah kejuruan (SMK) sederajat bahkan hingga diploma saat ini kurang diminati oleh lembaga dan perusahaan. Perusahaan atau lembaga lebih tertarik mencari calon karyawan dengan kualifikasi minimal lulusan sarjana/S1 sederajat sebagai upaya peningkatan kualitas. Hal ini terjadi karena kebutuhan atau formasi pekerjaan yang dibutuhkan, yang sudah tidak berfokus pada peningkatan kuantitas melainkan kualitas Akibatnya, peluang lapangan pekerjaan bagi lulusan SMA/SMK dan Diploma semakin minim; angka pengangguran pada angkatan kerja semakin meningkat. Tentunya fenomena tersebut menjadi hal yang harus segera diatasi dengan tepat.

Pengangguran produktif ini disebabkan oleh keterampilan sumber daya manusia yang kurang. Selain itu, minat lulusan berwirausaha juga minim. Melalui lembaga pendidikan, pemerintah dapat melakukan kebijakan terkait kewirausahaan sedini mungkin, tidak hanya di SMK saja tetapi termasuk di SMA. Hal ini dilakukan dengan cara memberikan wawasan dan membentuk karakter kewirausahaan pada diri peserta didik. Kebijakan pembangunan pendidikan nasional dimaksudkan agar peserta didik memiliki akhlak mulia, kreatif, inovatif (karakter wirausaha), karakter kebangsaan (Ratna, 2013:2). Selain itu, karakter kewirausahaan sangat 
dibutuhkan bagi negara yang sedang berkembang seperti di Indonesia (Ngadi, 2005:5). Pembentukan karakter tersebut akan menghasilkan SDM yang terampil yang memiliki jiwa kewirau sahaan dan mampu meningkatkan produktivitas dan daya saing di era global. Harapannya kemandirian bangsa meningkat serta peluang pekerjaan juga semakin banyak.

Pendidikan kewirausahaan bukan hanya menyampaikan landasan teoritis mengenai konsep kewirausahaan tetapi juga membentuk sikap, perilaku, dan pola pikir seorang wirausaha. Berdasarkan hasil wawancara pra penelitian di SMAN 1 Turi Sleman, peserta didik SMA masih merasa pengetahuan mereka tentang kewirau sahaan belum menjadi hal yang penting karena masih bergantung pada penghasilan orang tuanya. Sebagian besar peserta didik memahami wirausaha sebatas berdagang. Padahal konteks wirausaha sangat luas dan tidak hanya sekadar kegiatan jual beli. Hal yang sama juga ditemukan di SMAN 1 Playen bahwa siswa sudah lama mendapatkan pendidikan kewirausahaan, bahkan pendidikan kewirausahaan telah menjadi salah satu poin untuk promosi kepada masyarakat. Hanya saja fasilitas sekolah yang tersedia untuk praktik kewirausahaan masih terbatas.

Munculnya SMAN yang melaksanakan program kewirausahaan adalah implementasi Peraturan Menteri Pendidikan dan Kebudayaan (Permendikbud) Republik Indonesia Nomor 24 Tahun 2016 tentang Kompetensi Inti dan Kompetensi Dasar Pelajaran Pada Kurikulum 2013 Pada Pendidikan Dasar dan Pendidikan Menengah. Lampiran tersebut berisi terkait Kompetensi Inti dan Kompetensi Dasar Prakarya dan Kewirausahaan SMA/MA/SMK/MAK. Kebijakan itu diambil guna meningkatkan kompetensi wirausaha pada generasi muda bangsa. Oleh karena itu, di setiap kabupaten/kota ditunjuk beberapa SMA menjadi pelaksana program kewirausahaan.

Beberapa SMAN di Daerah Istimewa Yogyakarta juga ditunjuk sebagai sekolah percontohan dalam pengelolaan program kewirausahaan. Sekolah tersebut yaitu SMAN 6 Yogyakarta, SMAN 2 Banguntapan, SMAN 1 Turi, SMA N 1 Playen. Penelitian ini dilakukan di empat SMAN tersebut. Penelitian ini didorong oleh tingginya jumlah penduduk Indonesia dalam usia produktif tetapi masih menjadi pengangguran. Selain itu, masih banyak masyarakat yang berpikir langsung bekerja setelah lulus SMA dan tidak melanjutkan ke perguruan tinggi. Padahal lulusan SMA masih terbatas keterampilan dan pengetahuan wirausahanya. Melalui keterampilan dan pemahaman terkait kewirausahaan di sekolah, peserta didik diharapkan memiliki kemandirian, kreativitas, dan inovatif dalam berbagai hal agar di masa yang akan datang mereka dapat menghadapi permasalahan kehidupan, menciptakan lapangan pekerjaan, dan meningkatkan taraf 
kehidupan bangsa Indonesia. Santosa (2014) menjelaskan bahwa proses pengembangan kewirausahaan perlu dilaksanakan secara berkelanjutan sebagai proses sejak dini sebelum memasuki pendidikan di perguruan tinggi. Oleh karena itu, penelitian ini bertujuan untuk mengetahui pengelolaan program kewirausahaan SMA di Daerah Istimewa Yogyakarta.

\section{METODE PENELITIAN}

Jenis penelitian yang digunakan adalah penelitian deskriptif. Penelitian deskriptif bertujuan untuk menggambarkan atau menerangkan gejala, tidak menguji hipotesis (Arikunto, 2005: 234). Penelitian ini menerapkan pendekatan kualitatif yang dipertimbangkan sesuai untuk memahami realitas rasional sebagai realitas subjektif melalui proses observasi dan wawancara mendalam ketika mengumpulkan data. Penelitian ini dilaksanakan di empat SMAN di Daerah Istimewa Yogyakarta. Sekolah tersebut adalah SMAN 6 Yogyakarta, SMAN 2 Banguntapan, SMAN 1 Turi, dan SMAN 1 Playen. Penelitian ini dilaksanakan selama 2 bulan, yakni mulai bulan NovemberDesember 2017.

Subyek penelitian ini yaitu koordinator dan guru program kewirausahaan di setiap SMA. Kedua pihak tersebut memahami dan dapat memberikan informasi yang lengkap terkait dengan pengelolaan program kewirausahaan di SMAN yang diteliti. Objek penelitian ini adalah pengelolaan program yang mencakup perencanaan, pelaksanaan, dan evaluasi program kewirausahaan. Teknik pengumpulan data menggunakan wawancara, observasi, dan studi dokumentasi. Data penelitian ini diperoleh melalui wawancara, observasi, dan studi dokumentasi. Instrumen yang digunakan yaitu pedoman wawancara, pedoman observasi, dan pedoman studi dokumentasi. Kegiatan analisis data meliputi proses mencari dan menyusun secara sistematis data diperoleh dari hasil pengumpulan data (Sugiyono, 2010:335). Data yang diperoleh dalam penelitian ini merupakan data kualitatif sehingga teknik analisa yang digunakan dalam penelitian ini adalah analisis deskriptif kualitatif mengikuti model interaktif Milles, Huberman, dan Saldana.

\section{HASIL}

Hasil penelitian tentang pengelolaan program kewirausahaan di empat SMAN di Daerah Istimewa Yogyakarta meliputi perencanaan, pelaksanaan, dan evaluasi. Data penelitian diperoleh melalui wawancara dengan informan, observasi, dan studi dokumen. Hasil penelitian sebagai berikut: 


\subsection{Perencanaan program kewirausahaan}

Perencanaan ialah langkah awal dari suatu proses pengelolaan program. Perencanaan merupakan proses kegiatan yang menyiapkan secara sistematis kegiatan-kegiatan yang akan dilakukan untuk mencapai tujuan tertentu (Kurniadin \& Machali, 2013:126). Perencanaan program kewirausahaan di SMAN 6 Yogyakarta, SMAN 2 Banguntapan, SMAN 1 Turi, SMAN 1 Playen dilakukan setelah ditunjuk sebagai sekolah rintisan atau model sejak tahun 2016 oleh Direktorat Pembinaan SMA. Tindak lanjut dari penunjukkan ini yaitu kepala sekolah melakukan ko ordinasi dengan para staf wakil kepala sekolah. Perencanaan dilakukan melalui rapat persiapan program kewirausahaan dan sosialisasi kepada warga sekolah. Guru mempersiapkan kegiatan kewirausahaan melalui RPP berisikan materi, media, metode pembelajaran, nilai-nilai karakter wirausaha yang terkandung dalam kegiatan pembelajaran kewirausahaan. Sosialisasi program kewirausahaan dilakukan dengan mengumpulkan warga sekolah termasuk orang tua siswa. Hal ini dilakukan semua sekolah yang ditunjuk guna menyampaikan informasi kewirausahaan sekolah.

Latar belakang program kewirausahaan di atas diungkapkan oleh koordinator dari SMAN 1 Turi, sebagai berikut:

"Kalau di sini, ini kan termasuk SMA pinggiran ya, kemudian biasanya kelulusan memang rata-rata banyak yang tidak melanjutkan. Lebih dari separuh ya. Sekitar enam puluh persen lebih dan di sini lahannya masih sangat luas. Lahan tanahnya masih sangat lua s sehingga memungkinkan mengadakan program kewirausahaan untuk budidaya tanaman, budidaya perikanan, rekayasa, kemudian kerajinan" (W.ES.1.28112017)

Selanjutnya, wawancara yang dilakukan kepada informan dari SMA N 2 Banguntapan, diantaranya sebagai berikut:

"Berdasarkan Permen dari pemerintah terkait PKWU itu dari Kementerian eee apa namanya, Pengembang Peningkatan Mutu SMA itu. Kami berdasarkan surat perintah kami diminta untuk pengembangan PKWU di wilayah Yogyakarta ada empat sekolahan" (W.KU.1.04122017)

Sekolah-sekolah yang ditunjuk merupakan sekolah yang diberi amanat lembaga yang terkait untuk menjadi percontohan bagi sekolah-sekolah lain yang ingin menerapkan program tersebut. Beberapa alasan yang berbeda terkait program kewirausahaan oleh koordinator program dari SMA N 6 Yogyakarta, sebagai berikut:

"Jadi, disamping kemampuan akademik kita ingin menambah pembekalan kemampuan tentang berwirausaha karena di Indonesia orang yang berminat wirausaha masih sedikit. Orang-orang yang bergelut dalam kewirausahan dalam bidang wirausaha, maka mulai dari 
SMA ini kita coba mengangkat salah satunya dengan memberikan materi PKWU di kelas X dan XI."(W.AF.1.30112017)

Adapun hasil wawancara kepada informan terkait perencanaan program kewirausahaan secara sistemik di sekolah yaitu:

"Untuk kegiatan perencanaan kita melibatkan semua, dari siswa, guru KWU, guru pembimbing KUS itu untuk perencanaan sebelum mereka menyusun rancangan proposal perencanaan kegiatan .... Jadi, untuk SMA 2 Banguntapan ini secara kurikulum karena sudah total kurikulum 2013 jadi ada mata pelajaran KWU dan secara khusus ditunjuk sebagai pionir sebagai sekolah kewirausahaan sudah berjalan dua tahun" (W.SA.5.04122017)

Hal yang serupa juga disampaikan informan lainnya, yakni:

"Untuk perencanaan awal, akan dilaksanakan koordinasi kepala sekolah dengan staf, wakawaka. Sesuai dengan draf yang sudah disetujui di direktorat karena sebagai kepala sekolah dan kami sebagai PJP harus mengikuti sosialisasi dan workshop di direktorat ... Kemudian kami melakukan sosialisasi kepada warga sekolah, intern sosialisasi pada guru. Sosialisasi pada guru dan kepada siswa, kemudian kepada pengurus komite dan wali murid. Sehingga, yang terkait dengan sekolah ini sudah kita sosialisasikan supaya mereka tahu dan ikut mendukung, itu tahap awalnya. Kemudian prosesnya kita melakukan In House Training (IHT) kepada guru maupun kepada siswa.”(W.EW.13.07122017)

\subsection{Pelaksanaan program kewirausahaan}

Pelaksanaan program kewirausahaan merupakan bentuk implementasi perencanaan yang dilaksanakan dalam bentuk kegiatan. Pelaksanaan program kewirausahaan meliputi internalisasi nilai-nilai kewirausahaan melalui mata pelajaran, metode yang digunakan dalam pembelajaran, dan bentuk materi yang diberikan.

Pengorganisasian program kewirausahaan membutuhkan struktur organisasi guna membagi tugas dan peran dalam melaksanakan kegiatan. Struktur organisasi program kewirausahaan melibatkan beberapa pemangku kepentingan sekolah. Hal tersebut sesuai dengan hasil wawancara bersama koordinator program kewirausahaan dari SMA N 6 Yogyakarta yaitu:

"Pertama, penanggung jawab bapak kepala sekolah. Kemudian ada namanya PJP, saya selaku waka kesiswaan sebagai penanggung jawab program. Kemudian dari penanggung jawab program itu nanti ada guru KWU atau PKWU, ada guru PKWU satu guru tentang pengolahan, yang kedua guru tentang rekayasa dan kerajinan. Kemudian dari guru itu turun 
ke bawah ada yang namanya KUS, Kelompok Usaha Siswa. Kelompok Usaha Siswa itu satu kelompok kira kira 4-5 anak." (W.AF.4.30112017)

Hal yang serupa juga diungkapkan oleh wakil kepala sekolah SMA N 2 Banguntapan, sebagai berikut:

"Kepala sekolah kemudian PJnya Waka kurikulum, sekretaris, semua guru dan karyawan terlibat dalam kegiatan itu. Karena kami memilki 48 kelompok KUS, KUS itu kelompok usaha kecil yang putra putri kita...” (W.KU.5.04122017)

Selanjutnya, pendidikan kewirausahaan di SMA diinternalisasikan melalui mata pelajaran

tertentu. Beberapa hasil wawancara dengan guru-guru yang menjadi pengajar kewirausahaan adalah sebagai berikut.

"Jadi, bentuk nilai-nilai dalam kewirausahaan itu bisa kita lihat dari hasil karya mas. Hasil karya, kreativitas dan sebagainnya itu bisa di lihat dari buku. Termasuk juga dalam hal kemandirian, ini ada usaha hasil karya kelompok kemudian ada hasil karya individu yang bisa kita lihat dalam rangka internalisasi nilai kewirau sahaan, kita punya aspek -aspek untuk penilaian...”(W.SA.10.04122017)

Informan lainnya menambahkan banyaknya nilai-nilai kewirausahaan yang ditanamkan yakni:

"Banyak, jiwa wirausaha lebih kepada ketekunan. Itu membuat ketika mereka bekerja memiliki daya juang yang lebih tinggi. Akan nampak nanti ketika siswa pada pembelajaran mana yang daya juangnya lebih tinggi." (W.RK.6.07122017)

Metode yang ditetapkan disesuaikan dengan kondisi dan kebutuhan siswa. Materi pelajaran kewirausahaan membutuhkan metode yang variatif. Berikut hasil wawancara dengan beberapa guru-guru sebagai informan terkait metode yang digunakan.

"Praktek kita, jadi ceramah dan juga praktek. Jadi, biasanya ngajar itu sebenarnya pelajaran ceramah itu sudah tidak lagi diaplikasikan di K13. Jadi, di K13 itu siswa diberikan kasus, siswa kemudian memecahkan masalahnya, kemudian dishare. Nah, seperti itu, jadi biasanya saya hanya menyampaikan sepatah atau dua patah kata, nanti mereka berdiskusi saya berikan kasus kemudian mereka menyelesaikan itu dan untuk di lapangan dengan praktiknya dikasih modal kemudian harus menghabiskan, mereka harus mengembalikan itu bagian dari praktik secara langsungnya.”(W.AI.4.04122017)

Hal yang serupa juga dijelaskan oleh informan lainnya, yakni sebagai berikut:

"Jadi, untuk pertemuan pertama yang jelas harus dibekali dulu dengan materi teori. Misalkan, eeee kegiatan atau pertemuan atau Kompetensi Dasar(KD) yang membahas te ntang kerajinan dari bahan limbah, yang jelas anak harus diberi teori dulu, teorinya bagaimana, dan setelah itu dari guru memaparkan bentuk-bentuk kerajinan yang berkaitan dengan limbah bekas ini dan seterusnya, baru setelah pertemuan selanjutnya yang sete lah diprogramkan masinh-masing guru disiapkan untuk do nya jadi mereka melaksanakan praktik kewirausahaan. Masingmasing memiliki target sendiri-sendiri." (W.SA.6.04122017) 
Berikut ini penjelasan bentuk materi yang disampaikan kepada siswa, yaitu:

"Jadi, kewirausahaan itu ada 4 aspek yaitu rekayasa, budidaya, pengolahan, dan kerajinan... Sesuai dengan bidang, misalnya pengolahan, nanti praktik di dapurnya kita pengolahan, penilaiannya pengolahan.” (W.AI.6.04122017)

\subsection{Evaluasi program kewirausahaan}

Tahap evaluasi program terdiri dari pengawasan program, kendala dan upaya mengatasi kendala. Berikut ini adalah hasil wawancara tentang pengawasan kepada beberapa informan sebagai koordinator maupun penanggung jawab program.

"Ya, istilahnya pembimbing KUS. Pembimbing Kelompok KUS itu ada dua orang, satu kelompok dibimbing dua orang. Dua orang artinya begini, kalau seorang kelompok itu mau cari guru A pas kebetulan tidak ada, bisa ke guru B supaya memudahkan. Tidak ada alasan nggak ketemu pak." (W.AF.8.30112017)

Hal senada juga disampaikan oleh koordinator program kewirausahaan yang kami wawancarai lainnya.

"Untuk cara mengawasinya kita serahkan ke pembimbing KUS, sehingga pembimbing bertanggung jawab atas perencanaan sampai pelaporan. Diantaranya pengawasan setiap kegiatan itu masing-masing kelompok itu harus membuat dokumen foto atau video mulai dari persiapan sampai proses saja.”(W.EW.11.07122017)

Hanya saja masih ada beberapa kendala yang dialami pada program tersebut. Beberapa kendala tersebut diuraikan oleh beberapa guru yang menjadi narasumber atau informan sebagai berikut.

"Siswa terlalu banyak kegiatan di sini. Jadi, semua siswa di sini sibuk. Mereka sulit membagi waktunya, itu kendala dari siswa ... Itu kendalanya"(W.AI.11.04122017)

Hal senada juga diungkapkan oleh informan dari sekolah yang lain mengalami hal yang serupa, yakni:

"Lebih ke waktu, bagaimana anak bisa membagi waktu. Karena anak kan pulang jam 2 (dua). Kelas satu itu Jumat ada pramuka, sehingga mungkin kurang maksimal kebanyakan kekurangan waktu. Program kewirausahaan baru satu setengah tahun mungkin belum maksimal, akan dievaluasi untuk tahun berikutnya." (W.RK.10. 07122017)

Berikut ini penyampaian oleh beberapa informan, upaya-upaya yang dilakukan untuk mengatasi kendala pada program kewirausahaan di sekolah, yaitu:

"Memberikan ide-ide bisnis yang tidak menyita waktu mereka. Jadi, usaha makanan kalau masak harus pagi, kalau tidak mau seperti itu pilih kerajinan, itu dijualnya bisa sewaktuwaktu" (W.AI.12.04122017) 
Selain pernyataan diatas, hal berbeda disampaikan informan lainnya terkaitkendala sesuai dengan kondisi yang dialami, sebagai berikut:

"Iya, dengan kerjasama. Termasuk kendalanya saat liburan hehehehe. Sebentar lagi libur dua minggu, lha lele kalau prei rong minggu piye iki. Akhirnya biasanya pagi pagi panen, nanti misalnya mulai lagi setelah mulai KBM lagi. Jadi, pas liburan iki pas masa-masa panen. Sementara di lingkup sekolah, tapi kalo lele juga ada yang di luar sekolah.”

\section{PEMBAHASAN}

\subsection{Perencanaan program kewirausahaan}

Perencanaan ialah langkah awal dari sebuah proses pengelolaan program. Perencanaan merupakan proses kegiatan yang menyiapkan secara sistematis kegiatan-kegiatan yang akan dilakukan untuk mencapai tujuan tertentu (Kurniadin \& Machali, 2013:126). Selain itu, perencanaan juga diartikan sebagai sejumlah kegiatan yang ditentukan sebelumnya untuk dilaksanakan pada suatu periode tertentu dalam rangka mencapai tujuan yang ditetapkan.

Berdasarkan temuan hasil penelitian ini, perencanaan pengelolaan program kewirausahaan di SMA didasarkan pada penunjukkan sekolah-sekolah sebagai rujukan atau model penerapan kewirausahaan oleh Direktorat Tingkat Dasar dan Menengah Pusat. Kebijakan tersebut tertuang pada Peraturan Menteri Pendidikan dan Kebudayaan (Permendikbud) Republik Indonesia Nomor 24 Tahun 2016 tentang Kompetensi Inti dan Kompetensi Dasar Pelajaran Pada Kurikulum 2013 Pada Pendidikan Dasar dan Pendidikan Menengah, Lampiran Nomor 49.

Ula (2013:15) berpendapat bahwa perencanaan merupakan kegiatan untuk menetapkan pekerjaan yang harus dilakukan oleh suatu kelompok demi tercapainya tujuan yang telah disusun. Perencanaan tersebut mencakup kegiatan pengambilan keputusan, termasuk pemilihan alternatifalternatif keputusan. Program pendidikan kewirausahaan di SMA menjadi tanggung jawab kepala sekolah. Kepala sekolah bertanggung jawab karena melakukan perjanjian dengan pihak yang memberikan anggaran, dalamhal ini Kementerian Pendidikan dan Kebudayaan. Tim pelaksananya dipimpin oleh kepala sekolah dibantu dengan penanggung jawab, bendahara, sekretaris, koordinator yang sekaligus menjadi guru. Penanggung jawab bertugas untuk memberikan arahan, memonitor kinerja, dan menerima laporan pelaksanaan program. Koordinator dan guru berfungsi 
sebagai pelaksana program dengan pemberian materi, pembimbing, dan motivator kepada kelompok-kelompok usaha yang telah dibentuk.

Hasil di atas sesuai dengan penelitian Maulia (2019) tentang pengelolaan kegiatan kewirausahaan dalam pengembangan kreativitas peserta didik di SMKN 3 Banda Aceh. Hasilnya yaitu: 1) perencanaan kegiatan kewirau sahaan sudah direncanakan dengan baik dengan perumusan strategi, kebijakan, prosedur dan program yang jelas, (2) pelaksanaan kegiatan kewirausahaan untuk mengembangkan kreativitas berupa pemberian informasi, pengkajian teori dari berbagai informasi, melihat peluang pasar, menentukan tema dan prosedur produksi, mengajukan proposal perizinan pemasaran dan pembukuan. (3) Hambatan dalam pelaksanaan kegiatan kewirausahaan adalah hambatan kemampuan, hambatan psikologi, hambatan personal, hambatan sumber daya dan hambatan yang memandang kebiasaan.

Pengelolaan personalia merupakan sebuah proses penataan yang berkaitan dengan upaya memperoleh dan menggunakan tenaga kerja secara efisien demi tercapainya tujuan. Manajemen personalia merupakan proses penggunaan tenaga manusia sebagai tenaga kerja dalam suatu usaha kerja sama (Nawawi, 1998:25). Pengelolaan personil diawali dengan rapat pembuatan tim kewirausahaan yang disesuaikan dengan kebutuhan dan kemampuan sekolah. Kepala sekolah bertindak sebagai penanggung jawab, wakil kepala sekolah bertindak sebagai penanggung jawab program atau koordinator program, serta guru sebagai pelaksana program. Guru yang ditunjuk sebagai pelaksana selain mengajarkan konsep kewirausahaan juga membimbing setiap kelompok usaha siswa dalam melaksanakan kegiatan usaha.

\subsection{Pelaksanaan program kewirausahaan}

Pelaksanaan pendidikan kewirausahaan di sekolah dilaksanakan oleh seluruh warga sekolah. Hal ini menjadi upaya untuk menciptakan suasana kewirausahaan dan internalisasi nilai-nilai kewirausahaan. Nilai-nilai yang terdapat dalam pendidikan kewirausahaan yakni nilai dan ciri seorang wirau saha. Hal ini diungkapkan oleh Mulyani, dkk (2010:10) yakni terdapat 17 nilai dalam kewirausahaan yang dapat dikembangkan terhadap peserta didik sesuai dengan tingkat perkembangannya, di antaranya jujur, disiplin, kerja keras, kreatif, inovatif, mandiri, tanggung jawab, kerjasama, kepemimpinan, pantang menyerah, berani menanggung resiko, komitmen, realistis, rasa ingin tahu, komunikatif, motivasi kuat untuk sukses dan berorientasi pada tindakan. 
Sesuai dengan pendapat Siregar et al. (2018), disebutkan bahwa program kewirausahaan bertujuan untuk membuat karakter siswa yang memiliki kemampuan kewirausahaan selain menjadi siswa kreatif, inovatif dan mandiri. Pelaksanaan program kewirausahaan yang disampaikan oleh guru harus sesuai dengan modul atau peraturan yang berlaku. Namun demikian, pada kondisi tertentu, sekolah diperbolehkan untuk melakukan inovasi dan memperluas kajian tentang kewirausahaan. Harapannya pada penerapannya siswa antusias dan mampu memberikan feedback (Suherman, 2010:108).

Berdasarkan temuan hasil penelitian, pelaksanaan program kewirausahaan memiliki nilainilai beragam yang sangat penting bagi siswa dalam pembelajaran sekolah. Harapannya, para siswa memiliki nilai percaya diri, kreativitas, kemandirian, rasa tanggung jawab, inovatif, hingga mampu mencari ide peluang usaha. Pada pelaksananya, nilai-nilai tersebut memang telah disiapkan dan disematkan dalam sebuah Rencana Pelaksanaan Pembelajaran(RPP). Seperti halnya di dalam kompetensi dasar terdapat nilai kewirausahaan yakni berorientasi ke masa depan dan berani mengambil resiko.

\subsection{Evaluasi program kewirausahaan}

Evaluasi program adalah proses untuk mengetahui apakah tujuan pendidikan telah terealisasikan (Arikunto, 2009:5). Evaluasi merupakan suatu kegiatan guna mengamati hal-hal yang perlu diperbaiki dalam kegiatan, pada konteks ini adalah kegiatan pembelajaran kewirausahaan. Kegiatan evaluasi pada hal ini ditujukan kepada siswa dan guru. Evaluasi siswa dapat diukur dari nilai akademis, nilai praktis, dan nilai pragmatis. Sedangkan evaluasi untuk guru meliputi kesesuaian job description dan job spesification. Hal ini dilihat juga terkait ketercapaian program yang dilaksanakan (Suherman, 2010:108).

Berdasarkan temuan hasil penelitian, program kewirausahaan di SMA yang diteliti melakukan kegiatan evaluasi guna meningkatkan kualitas kedepannya. Berbagai upaya juga telah dilakukan agar kualitas dan mutu pelaksanaan kewirausahaan sesuai dengan rencana yang telah ditetapkan. Upaya tersebut antara lain guru memonitor kegiatan kewirausahaan siswa di sekolah seperti kegiatan jual beli secara langsung. Guru juga mengevaluasi secara tidak langsung kegiatan kewirau sahaan siswa melalui dokumentasi berupa foto, video, dan laporan keuangan, seperti foto kegiatan jual beli, video kegiatan produksi, dan laporan penggunaan modal dari sekolah. 
Penilaian kegiatan siswa dalam berwirausaha yang utama dilihat dari laporan keuangan. Setiap kelompok diberikan modal untuk berwirausaha, harapannya kelompok yang berhasil mampu mengembalikan modal awal kembali ke sekolah. Jika sebaliknya, kelompok yang adanya kemungkinan mengalami kerugian, maka guru akan memberi arahan dan petunjuk untuk memperbaiki setidaknya tidak mengalami kerugian yang banyak. Laporan tersebut oleh guru olah dan menjadi acuan penilaian akhir kepada siswa.

Beberapa hambatan siswa yang muncul dalam penyelenggaraan program kewirausahaan yaitu pembagian waktu belajar. Program ini tidak bisa dipungkiri akan mengambil porsi waktu belajar siswa karena materi kewirausahaan merupakan satuan mata pelajaran yang tergabung dengan prakarya. Selain itu, beragam kegiatan di sekolah dan jam belajar yang cukup banyak membuat siswa merasa kesulitan untuk membagi waktu. Hal ini mengakibatkan semangat dan motivasi siswa naik turun yang nantinya akan berpengaruh pada proses dan hasil program tersebut. Kesulitan membagi waktu ini sesuai dengan pendapat O'Connor(2016) dan Pawestri et al. (2019).

Kemampuan guru juga masih sebatas memberi pengarahan dan belum banyak yang menguasai aspek-aspek kewirau sahaan di sekolah. Hasil penelitian ini menunjukkan motivasi serta daya pikir kreatif siswa masih kurang karena kemampuan guru memberi motivasi masih terbatas. Selain itu, fasilitas juga menjadi kendala. Sarana dan media yang dimiliki sekolah sangat terbatas karena berkaitan dengan penganggaran. Selain itu, melihat kondisi yang dialami saat ini, praktik kewirausahaan dialihkan online. Kegiatan on ini kadang masih memiliki kendala pada terbatasnya jaringan internet. Hal ini sesuai dengan hasil penelitian Pawestri et al. (2019), perlu adanya peningkatan kapasitas guru terhadap penyelen ggaraan program kewirausahaan di sekolah.

\section{SIMPULAN}

Berdasarkan hasil penelitian dan pembahasan dapat disimpulkan beberapa hal sebagai berikut. 1) Perencanaan program kewirausahaan SMAN di DIY meliputi penetapan tujuan, perencanaan program, perencanaan pembiayaan, dan perencanaan personil. Program kewirausahaan di SMAN membekali ilmu dan keterampilan siswa agar memiliki mental dan jiwa wirausaha. Program ini bertujuan untuk memberikan ilmu berwirausaha bagi siswa. 2) Pelaksanaan program kewirausahaan meliputi tahap pengorganisasian, koordinasi, dan implementasi kurikulum program kewirausahaan. Pengorganisasian program kewirausahaan dilakukan dengan cara membentuk tim kewirausahaan. Perencanaan personil dilakukan dengan menyusun individu-individu dalam 
sebuah tim kewirausahaan sekolah. Koordinasi dilakukan secara horizontal dan vertikal melalui pembentukan tim. Pengelolaan kurikulum kewirausahaan dilakukan dengan internalisasi nilai kewirausahaan, metode dan pemilihan bentuk materi yang disampaikan. 3) Evaluasi program kewirausahaan dilakukan pada setiap akhir semester oleh tim kewirausahaan sekolah. Implikasi dari penelitian ini adalah pentingnya pendidikan kewirausahaan sejak dini sebagai bagian dalam upaya membangun kesadaran dan motivasi berprestasi. Jiwa kewirausahaan harus ditumbuhkan melalui pola tertentu agar berhasil khususnya di sekolah.

\section{DAFTAR PUSTAKA}

Arikunto, S. (2005). Manajemen penelitian. Jakarta: Rineka Cipta.

Arikunto, S. (2009). Dasar-Dasar Evaluasi Pendidikan. Jakarta: Bumi Aksara.

Badan Pusat Statistik. (2016). Metadata sensus ekonomi 2016 lanjutan. Jakarta: Badan Pusat Statistik.

Kementerian Pendidikan dan Kebudayaan.(2016). Peraturan Menteri Pendidikan dan Kebudayaan Republik Indonesia Nomor 24 Tahun 2016 tentang kompetensi inti dan kompetensi dasar pelajaran pada kurikulum 2013 pada pendidikan dasar dan pendidikan menengah.

Kurniadin, D. \& Machali, I. (2013). Manajemen pendidikan: Konsep \& prinsip pengelolaan pendidikan. Yogyakarta: Ar-Ruzz Media.

Maulia, Rahma., (2019). Pengelolaan kegiatan kewirausahaan dalam pengembangan kreativitas peserta didik di SMKN 3 Banda Aceh. Banda Aceh: Universitas Islam Negeri ArRaniry.

Mulyani, E. et al. (2010). Pengembangan pendidikan kewirausahaan. Jakarta: Badan Penelitian dan Pengembangan Kurikulum.

Nawawi, H. (1998). Administrasi pendidikan. Jakarta: Ghalia Indonesia.

Ngadi. (2005). Model pengembangan kewirausahaan (entrepreneurship) di sekolah melalui strategi berbasis sekolah Madura: Modul dalam rangka hari guru nasional internasional dengan penyelenggara PGRI Kabupaten Sumenep Tahun 2005 Tanggal 30 Nopember 2005: Universitas Wiraraja.

O'Connor, D. (2016). The golden thread: educator connectivity as a central pillar in the development of creativity through childhood education. An Irish life history study. Education 3-13, 44(6), 671-681. https://doi.org/10.1080/03004279.2014.999343

Pawestri, G. W., Sumantri, M. S., \& Utomo, E. (2019). Evaluasi program kewirausahaan di SDK21 Penabur. Jurnal Basicedu, 3(3), 1-12. https://doi.org/10.31004/basicedu.v4i1.172

Ratna, L. (2013). Analisis nilai-nilai kewirausahaan dalam pembelajaran ips di sekolah dasar. Tesis. Bandung. Pasca Sarjana UPI.

Santosa, I. (2014). Masalah dan tantangan pengembangan kewirausahaan pada kalangan mahasiswa di Indonesia. Jurnal Inovasi Dan Kewirausahaan, 3(3), 203-207. https://doi.org/10.20885/ajie.vol3.iss3.art5

Siregar, Y. E. Y., S, Z. M., W, P. A., Rachmadtullah, R., \& Pohan, N. (2018). Self regulation, emotional intelligence with character building in elementary school. https://doi.org/10.2991/acec-18.2018.72 
Sugiyono. (2010). Metode Penelitian Pendidikan Pendekatan Kuantitatif, kualitatif, dan R\&D. Bandung: Alfabeta.

Suherman, E. (2010). Desain pembelajaran kewirausahaan. Bandung: Alfabeta.

Ula. S. (2013). Revolusi belajar. Yogyakarta: Ar-Ruzz Media. 